\title{
Dorsal Column Degeneration after Bortezomib Therapy in a Patient with Multiple Myeloma
}

\author{
Tatsuro Joh $^{a}$ Kazuto Sigematu ${ }^{b}$ Jun-ichi Yasui ${ }^{a}$ \\ Yumi Takasaki ${ }^{a}$ Masayuki Tawara ${ }^{a}$ Osamu Takaharab \\ Masao Tomonaga ${ }^{a}$ \\ a Department of Internal Medicine and ${ }^{b}$ Department of Pathology, Japanese Red \\ Cross Society Nagasaki Genbaku Hospital, Nagasaki, Japan
}

\section{Key Words}

Bortezomib - Multiple myeloma $\cdot$ Peripheral neuropathy $\cdot$ Dorsal column degeneration

\begin{abstract}
We present here a case of dorsal column degeneration in a female patient with multiple myeloma following exposure to bortezomib. Two days after intravenous administration of a first course of bortezomib $1 \mathrm{mg} / \mathrm{m}^{2}$, the patient developed rapidly-progressive numbness, pain and muscle weakness in the bilateral upper and lower limbs. Following gancyclovir treatment of subsequent cytomegalovirus viremia, the patient went on to receive a course of EPOCH (etoposide $50 \mathrm{mg} / \mathrm{m}^{2} /$ day on days $1-4$, vincristine $0.4 \mathrm{mg} / \mathrm{m}^{2} /$ day on days $1-4$, doxorubicin $10 \mathrm{mg} / \mathrm{m}^{2} /$ day on days $1-4$, cyclophosphamide $750 \mathrm{mg} / \mathrm{m}^{2} /$ day on day 6 , and prednisolone $60 \mathrm{mg} / \mathrm{m}^{2} /$ day on days $\left.1-6\right)$. Shortly thereafter, the patient developed bilateral Aspergillus pneumonia. Despite treatment with appropriate antifungal agents, the patient died from respiratory failure due to bilateral diffuse alveolar damage of the lungs and without recovery of severe sensory and motor neuropathy prior to her death. Post mortem examination revealed spongy degeneration of the dorsal column from the medulla oblongata to the cervical spinal cord. Bortezomib-associated peripheral neuropathy in patients with multiple myeloma has been commonly reported but appears to resolve in a majority of these patients after dose reduction or discontinuation. We believe this to be the first report of spinal cord abnormalities in a patient with multiple myeloma treated with bortezomib. Further investigation is required to ascertain the exact mechanism of this central neurotoxic effect and to identify appropriate neuroprotective strategies.
\end{abstract}




\begin{tabular}{|c|c|c|c|}
\hline $\begin{array}{c}\text { Cose Reports in } \\
\text { Bnatily }\end{array}$ & $\begin{array}{l}\text { Case Rep Oncol 2009;2:184-188 } \\
\text { D0I: } 10.1159 / 000231996\end{array}$ & Published online: October 14, 2009 & $\begin{array}{l}\text { (c) } 2009 \text { S. Karger AG, Basel } \\
\text { ISSN } 1662-6575 \\
\text { www.karger.com/cro }\end{array}$ \\
\hline
\end{tabular}

\section{Introduction}

Multiple myeloma remains an incurable hematological disorder. Bortezomib, the firstin-class proteasome inhibitor, has been shown to have significant antitumor activity in the treatment of relapsed/refractory patients with this condition $[1,2]$. The main doselimiting toxicity of bortezomib is peripheral neuropathy, which requires dose modification and potential changes to the treatment plan when present [3]. The precise mechanism of this toxicity is not fully understood. Herein we report a case of degeneration of the dorsal column of the central nervous system from the medulla oblongata to the cervical spinal cord in a patient with multiple myeloma after a first course of bortezomib chemotherapy. Despite no further exposure to bortezomib, the patient's neurological abnormalities failed to show any resolution prior to her death. Eventual cause of death was respiratory failure due to bilateral diffuse alveolar damage of the lungs.

\section{Case Presentation}

A 64-year-old female patient was diagnosed with multiple myeloma (IgG, $\kappa$ light-chain isotype, stage IIIA) in May 2008. Laboratory examination revealed elevation of serum IgG (2,196 mg/dl), IgG- $\kappa$ type Bence-Jones protein in urine, proliferation of multiple myeloma cells in sternum bone marrow (about $54 \%$ ), anemia (hemoglobin $7.9 \mathrm{~g} / \mathrm{dl}$ ), hypercalcemia $(11.5 \mathrm{mg} / \mathrm{dl}$ ), elevation of serum $\beta 2$ microglobulin $(8.8 \mathrm{mg} / \mathrm{l})$, and multiple osteolytic lesions, including pathological fractures (cranium, clavicular bones, scapulas, radial bones, brachia, femurs, and tibiae). As initial treatment, dexamethasone $40 \mathrm{mg} / \mathrm{day}$ on days 1-4 along with zoledronic acid hydrate $4 \mathrm{mg}$ on day 1 was administered intravenously from 28 May 2008. On 4 June 2008, a herpes zoster skin eruption appeared on the lower left limb, which was treated with acyclovir. Following healing of the skin eruption, bortezomib $1 \mathrm{mg} / \mathrm{m}^{2}$ was administered intravenously on days 1, 4, 8 and 11 from 24 June to 4 July 2008. On 6 July 2008, the patient developed numbness, pain and muscle weakness in the bilateral upper and lower limbs. The symptoms progressed rapidly and the patient was bedridden within a few days. Magnetic resonance imaging of the brain and whole spine failed to reveal any abnormalities including cord compression. Treatment with vitamin $\mathrm{B}_{12}$ was ineffective. Cytomegalovirus (CMV) infection was detected on 25 July 2008 and treated with gancyclovir. After improvement of CMV viremia, a course of EPOCH chemotherapy (etoposide 50 $\mathrm{mg} / \mathrm{m}^{2} /$ day on days $1-4$, vincristine $0.4 \mathrm{mg} / \mathrm{m}^{2} /$ day on days $1-4$, doxorubicin $10 \mathrm{mg} / \mathrm{m}^{2} /$ day on days $1-4$, cyclophosphamide $750 \mathrm{mg} / \mathrm{m}^{2} /$ day on day 6 , and prednisolone $60 \mathrm{mg} / \mathrm{m}^{2} /$ day on days $1-6$ ) was administered beginning on 21 August 2008. Bilateral Aspergillus pneumonia occurred on 5 September 2008. Despite treatment with appropriate antifungal agents, the patient died in the autumn of 2008 from respiratory failure without recovery of severe sensory and motor neuropathy.

Post mortem examination revealed spongy degeneration of the dorsal column from the medulla oblongata to the cervical spinal cord, which likely triggered the neurological abnormalities. Spongy degeneration of the dorsal column was noted by hematoxylin-eosin staining, and damage to neuron and neural fibers was ascertained by luxol fast blue staining (fig. 1). As regards the patient's multiple myeloma, only remnants of myeloma cells were observed in the bone marrow, and there was no evidence of myeloma cell infiltration to other organs, indicating that chemotherapy including bortezomib was effective. Bilateral diffuse alveolar damage of the lungs was determined as the cause of death; however, no trace of fungal or bacterial pneumonia was evident.

\section{Discussion}

Bortezomib-induced peripheral neuropathy has been commonly reported $[3,4]$ but, to our knowledge, there have been no reports to date of spinal cord abnormalities in patients with multiple myeloma treated with bortezomib. After administration of bortezomib in a Wistar rat model, mild-to-moderate pathological changes in Schwann cells and myelin were observed along with satellite cell intracytoplasmic vacuolization in the dorsal root ganglia due to mitochondrial and endoplasmic reticulum damage; however, the spinal 
cord was confirmed as morphologically normal in this model [5]. In the present case, the patient had not previously been exposed to other neurotoxic agents such as vincristine or thalidomide, and severe progressive neurological abnormalities appeared after the first course of bortezomib. Although the peripheral neuropathy associated with bortezomib appears to be reversible in a majority of patients after dose reduction or discontinuation [4], no resolution of central neurological abnormalities was observed in this patient prior to her death.

In summary, we have experienced a multiple myeloma patient with spongy degeneration of the dorsal column from the medulla oblongata to the cervical spinal cord after bortezomib treatment. The neurological abnormalities were severe and irreversible. Bortezomib is a promising salvage agent for relapsed/refractory multiple myeloma; however, the associated nerve damage and its development are unpredictable at present. Further investigation is required to clarify the mechanism of bortezomib-induced neurotoxicity and to develop effective prevention and treatment methods against such an effect.

\section{Acknowledgement}

The authors would like to thank Kerry Dechant and Content Ed Net for editorial assistance. 


\begin{tabular}{c|l|l|l}
$\begin{array}{c}\text { Cose Reports in } \\
\text { Oncolady }\end{array}$ & $\begin{array}{l}\text { Case Rep Oncol 2009;2:184-188 } \\
\text { D0I: 10.1159/000231996 }\end{array}$ & Published online: October 14, 2009 & $\begin{array}{l}\text { O 2009 S. Karger AG, Basel } \\
\text { ISSN 1662-6575 } \\
\text { www.karger.com/cro }\end{array}$ \\
\hline
\end{tabular}

Fig. 1. Spongy degeneration of the spinal cord dorsal column in a patient with multiple myeloma.

a, c Hematoxylin-eosin staining; loupe and $\times 40$. b, d Luxol fast blue staining; $\times 40$ and $\times 200$.
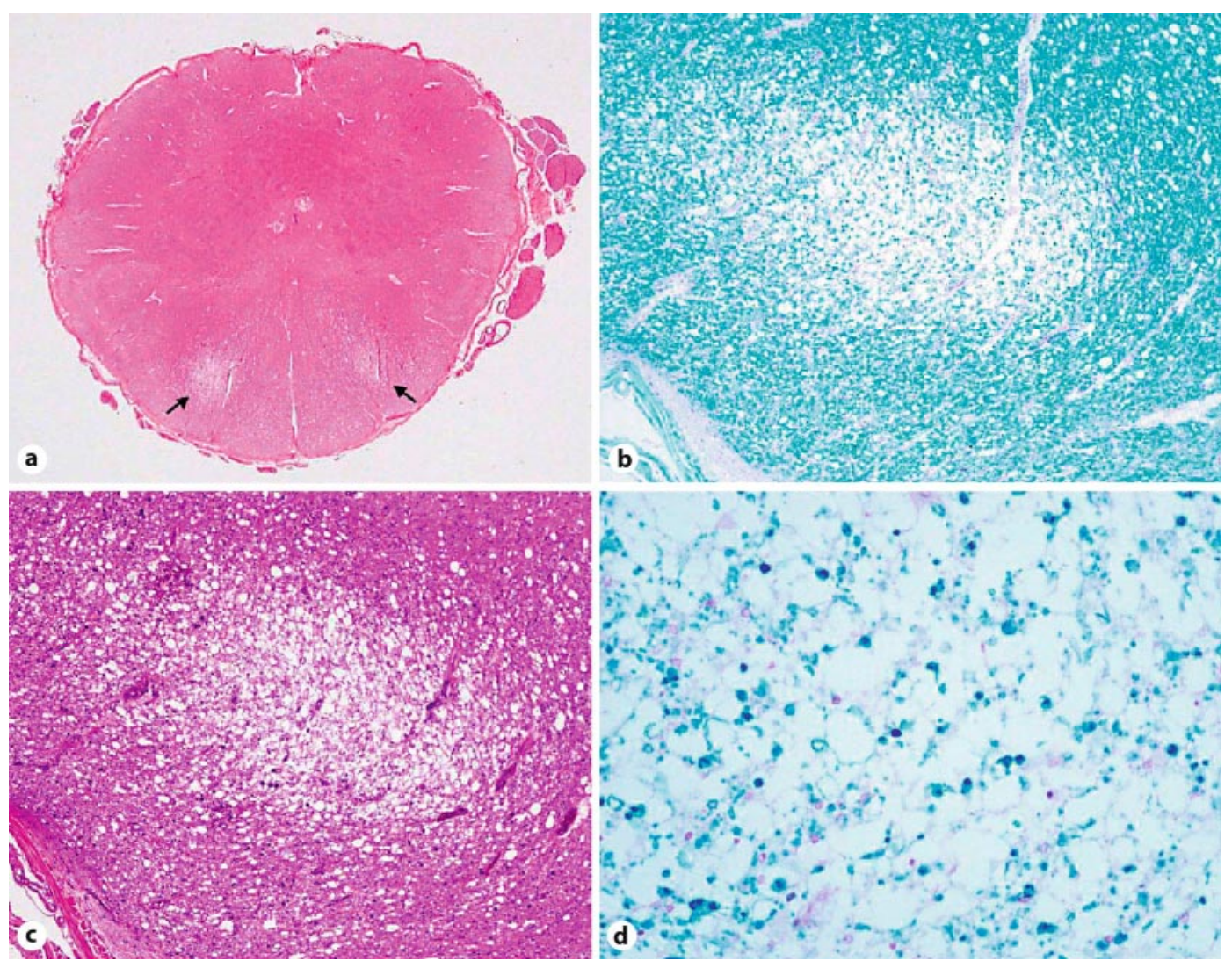


\section{References}

1 Richardson PG, Barlogie B, Berenson J, Singhal S, Jagannath S, Irwin D, Rajkumar SV, Srkalovic G, Alsina M, Alexanian R, Siegel D, Orlowski RZ, Kuter D, Limentani SA, Lee S, Hideshima T, Esseltine DL, Kauffman M, Adams J, Schenkein DP, Anderson KC: A phase 2 study of bortezomib in relapsed, refractory myeloma. N Eng J Med 2003;348:2609-2617.

-2 Richardson PG, Sonneveld P, Schuster MW, Irwin D, Stadtmauer EA, Facon T, Harousseau JL, Ben-Yehuda D, Lonial S, Goldschmidt H, Reece D, San-Miguel JF, Bladé J, Boccadoro M, Cavenagh J, Dalton WS, Boral AL, Esseltine DL, Porter JB, Schenkein D, Anderson KC; Assessment of Proteasome Inhibition for Extending Remissions (APEX) Investigators: Bortezomib or high-dose dexamethasone for relapsed multiple myeloma. N Eng J Med 2005;352:2487-2498.

3 Badros A, Goloubeva O, Dalal JS, Can I, Thompson J, Rapoport AP, Heyman M, Akpek G, Fenton RG: Neurotoxicity of bortezomib therapy in multiple myeloma: a single-center experience and review of the literature. Cancer 2007;110:10421049.

4 Richardson PG, Sonneveld P, Schuster MW, Stadtmauer EA, Facon T, Harousseau JL, Ben-Yehuda D, Lonial S, Goldschmidt H, Reece D, Bladé J, Boccadoro M, Cavenagh JD, Boral AL, Esseltine DL, Wen PY, Amato AA, Anderson KC, San Miguel J: Reversibility of symptomatic peripheral neuropathy with bortezomib in the phase III APEX trial in relapsed multiple myeloma: impact of a dose-modification guideline. Br J Haematol 2009;144:895-903.

5 Cavaletti G, Gilardini A, Canta A, Rigamonti L, Rodriguez-Menendez V, Ceresa C, Marmiroli P, Bossi M, Oggioni N, D’Incalci M, De Coster R: Bortezomibinduced peripheral neurotoxicity: a neurophysiological and pathological study in the rat. Exp Neurol 2007;204:317-325. 